\title{
A Study of Academic Achievement of School Students having illiterate and literate parents
}

\author{
Mrs. Malkeet Kaur
}

\section{ABSTRACT}

Asst. Professor M.S.K.K.C.E., Patiala.

The study aims to study the academic achievement of school students having illiterate and literate parents. The sample of the study comprised of 100 school students from Hoshiarpur district of Punjab. The findings indicated that students having literate parents scored higher than the students having illiterate parents.

\section{Keywords}

Academic Achievement; Illiteracy; Advancement.

\section{INTRODUCTION}

In the changing scenario, highly successful persons in academics are considered to be responsible to bring and maintain advancement of the society. Salami (2010) opined that academic success is the major goal of the college students for it has always been used as the main basis to judge the potentialities and capabilities and also as a means for selection for educational advancement and employment. Krishnan (1977) conducted a study on non-intellectual factors and their influence on academic achievement. The sample comprised of 180 students of sixth to ninth class studying in central school Tirupati and was divided into three groups depending on their parents' education as high, middle and low. The results indicated that parents' educational status had significant influence on the academic achievement of their children. Saini (1977) undertook a study on academic achievement as a function of economic status and educational standard of parents. The sample consisted of 196 students from four colleges of Chandigarh. The findings revealed that educational standard of parents had significant effect on the academic achievement of arts and science students at the college level. Singh and Srivastava (1983) investigated the impact of parents' literacy on the academic achievement on a sample of 85 first grade and 80 fifth grade students of Punjab in India. Students' scores on an achievement test were taken as measures of academic achievement of the students. The findings indicated that parents' literacy had a positive relationship with younger students' academic achievement. Sharma (1984) conducted a study on academic achievement of school students vis-à-vis their parents' education. The sample comprised of 230 ninth class students of Punjab from whom the data for the educational level of their parents were collected and analysed. The findings revealed that parental education was positively and significantly associated with academic achievement of their children. Baker and David (1986) recognized mothers' strategies for children's school achievement. The investigator collected data from heterogeneous sample of mothers of eighth graders through interview schedule. The results also indicated that parents actively manage their children's school career in a way that could have direct consequences for their children's academic achievement. Mother's education levels were found to influence academic achievement of the students through parental involvement and parental encouragement. Chakrabarti (1986) investigated academic achievement of primary school children. Data were collected from a sample of 100 boys from two English medium schools of Pune. Results indicated that the children whose parents were highly educated had better performance in both school examinations and achievement tests than those children whose parents were less educated. Bhatnagar and Sharma (1992) carried out a research to investigate the relationship between education of parents and academic achievement of students on a sample of 85 school students of semi-rural settings in Rajasthan. The results revealed that the children whose parents were educated performed higher in academics than the children whose parents were illiterate. Further the results indicated that parental education was significantly related to the academic achievement of the students. Bahago (2011) investigated the influence of achievement motivation and demographic characteristics on academic performance of nomadic Fulani girls in Adamawa state. The data were collected from a sample of 300 girls selected from nomadic primary schools by administering achievement motivation rating scale and nomadic girls' achievement test. The results indicated that academic achievement of the girls was influenced by parental education levels. The findings revealed the relevance of parental

\section{Council for Innovative Research}

Peer Review Research Publishing System

Journal of Social Science Research

\author{
Vol.1, No.1 \\ editor@ijssronline.com \\ www.cirworld.com, www.ijssronline.com
}


education in academic achievement of the girls. Kazmi (2011) conducted the study to evaluate the impact of fathers' style of dealing with their children at home and their academic achievements at school. The sample of the study consisted of 300 students, 300 fathers and 20 teachers which were drawn randomly from urban and rural areas of district Mansehra of Pakistan. The indigenously designed questionnaire was used to collect the data and academic achievement was taken from classroom records. The results of this study revealed fathers' involvement had positive significant relationship with academic achievement for the academic achievements. Sharma and Tahira (2011) investigated the influence of parental education, parental occupation and family size on science achievement of the secondary school students in western Uttar Pradesh in India. 1500 students were selected as a sample for the study and data was collected through a questionnaire that assessed personal information and science achievement test developed by the researchers themselves. The results indicated that family variables including parental education had significant relationship with the achievement of their children.

By reviewing these researches the investigation reaches to the point that academic achievement, serve as means to satisfy one's needs and derives with the desired success. Hence it is very important to enhance academic success to enable the school students attain the optimum level of education for their entire satisfaction. So, the investigator aims to study academic achievement of school students having literate and illiterate parents.

\title{
Objective
}

To study the Academic Achievement of school students with regard to educational status of their parents.

\section{Hypothesis}

There is no significant difference between academic achievement of school students with regard to educational status of their parents.

\section{Delimitation}

The study was confined only to tenth grade students of Government schools of Hoshiarpur district of Punjab.

\section{Method}

The study was conducted through descriptive method of survey.

\section{Sample}

The sample comprised of 100 tenth grade students of Government schools of Hoshiarpur district of Punjab. Further they were divided into two groups of 50 students each according to the educational status of their parents.

\section{Tools}

\section{Personal Data Form}

Records of Academic Achievement from the school authorities.

\section{Results}

Frequency Distribution of Academic Achievement Scores of School Students having Illiterate Parents

To know the academic achievement of students having illiterate parents, the frequency distributions along with the descriptive statistics are derived as given in table 1

\section{Council for Innovative Research}

Peer Review Research Publishing System

Journal of Social Science Research

\author{
Vol.1, No.1 \\ editor@ijssronline.com \\ www.cirworld.com, www.ijssronline.com
}




\title{
Table 1
}

Frequency Distribution of Academic Achievement Scores of School Students having Illiterate Parents

\begin{tabular}{|l|l|l|}
\hline Class Interval & Frequency & \\
\hline $71-80$ & 2 & 4 \\
\hline $61-70$ & 8 & 16 \\
\hline $51-60$ & 20 & 40 \\
\hline $41-50$ & 12 & 24 \\
\hline $31-40$ & 8 & 16 \\
\hline Total & 50 & 100 \\
\hline
\end{tabular}

As is clear from the table 1, the mean and median of the students having illiterate parents are 52.3 and 53 respectively. Whereas mode is calculated as 54.4 , it shows that the scores lie nearly in normal distribution. The table also shows that $20(40 \%)$ students having illiterate parents scored between 51 and 60 that is the class interval which contains mean scores (52.3) of the group. It also shows that $20(40 \%)$ students scored between 31 and 50 which is below the class interval that contains mean, whereas $10(20 \%)$ students scored between 61 and 80 which is above the class interval that contains mean of the group.

\section{Frequency Distribution of Academic Achievement Scores of Students having literate Parents}

To study the academic achievement of students having literate parents, the frequency distributions along with the descriptive statistics were derived and given in table 2 .

\section{Table 2}

Frequency Distribution of Academic Achievement Scores of Students having literate Parents

\begin{tabular}{|l|l|l|}
\hline Class Interval & Frequency & Percentage \\
\hline $71-80$ & 10 & 20 \\
\hline $61-70$ & 8 & 16 \\
\hline $51-60$ & 22 & 44 \\
\hline $41-50$ & 7 & 14 \\
\hline $31-40$ & 3 & 6 \\
\hline Total & 50 & 100 \\
\hline Mean: 58.5 & Median: 57.3 & Mode: 54.9
\end{tabular}

As is clear from the table 2, the mean and the median of academic achievement scores of school students having literate parents are 58.5 and 57.3 respectively whereas mode came out to be 54.9 . It is also clear that $22(44 \%)$ students lie in the class interval 51 to 60 in which mean exists and $18(36 \%)$ students lie in the class interval of 61 to 80 which is above than

\section{Council for Innovative Research}

Peer Review Research Publishing System

Journal of Social Science Research

\author{
Vol.1, No.1 \\ editor@ijssronline.com \\ www.cirworld.com, www.ijssronline.com
}


the class interval in which mean exists, whereas $10(20 \%)$ students lie in the class interval of 31 to 50 which is below than the class interval in which mean exists. The table also shows that maximum frequency (22) lies in the class interval 51-60 and minimum frequency (3) lies in the class interval 31-40.

\title{
Comparison of Academic Achievement of School Students with Regard to Educational Status of their Parents.
}

To study the difference in academic achievement of the students having illiterate and literate parents, the comparison was made by calculating significance of difference between mean scores of school students having literate and illiterate parents as given in table 3.

\section{Table- 3}

\section{Comparison of the Academic Achievement of School Students Having Illiterate and Literate Parents}

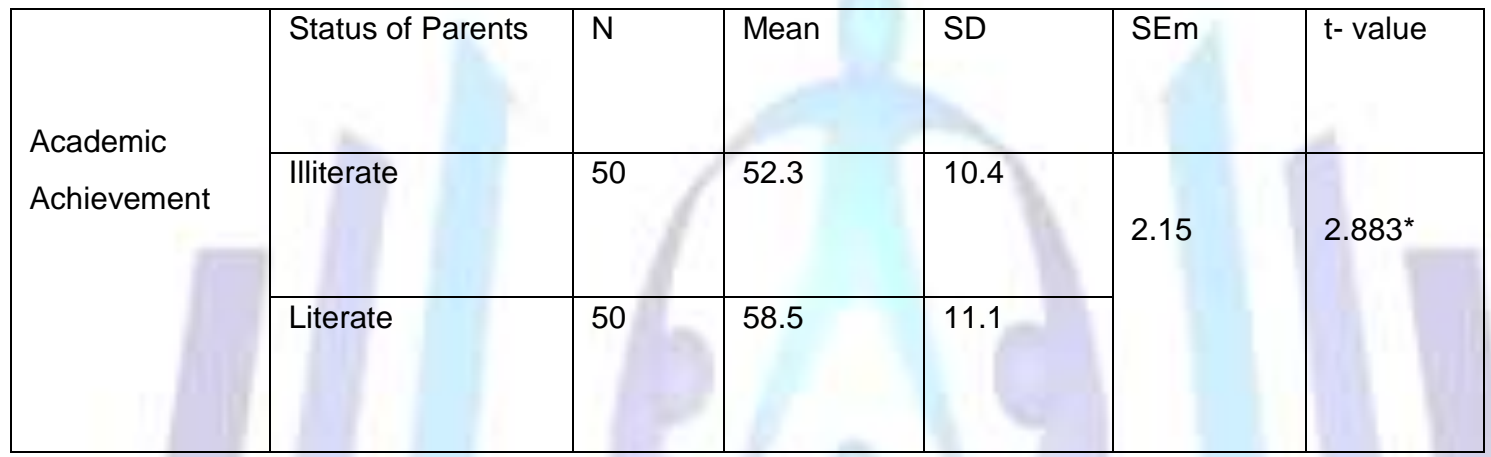

\section{${ }^{*} \mathrm{P}<0.01$}

It is clear from table 3 that mean value of school students having illiterate and literate parents are 52.3 and 58.5 respectively, with standard deviation 10.4 and 11.1. Standard error of mean difference came out to be 2.15 and t-value came out to be 2.883 which is significant at 0.01 level. This shows significant difference in academic achievement of the school students having illiterate and literate parents. From the means scores it is clear that the students belonging to literate parents have better academic achievements than their counterparts having illiterate parents. Thus, the hypothesis that there is no significant difference between academic achievement of school students with regard to educational status of their parents is rejected. This may be because literate parents provide their children better learning environment, more opportunities and greater exposure to educational field.

\section{REFERENCES}

[1] Bahago,Beatrice Ahmadu (2011) Intelligence of Achievement Motivation and Demographic Characteristic on Academic Performance of Nomadic Fulani Girls in Adamawa State. Submitted to the School of Postgraduate Studies, University of Jos. Retrieved from Internet on July 20, 2011.

[2] Baker, D. P. and David L. (1986) Mothers' Strategies for Children's School Achievement: Managing the Transition to High School. Sociology of Education, 59, 59, 156-166.

[3] Bhatnagar, J. K. and Sharma, M. (1992) A Study of the Relationship Between Parental Education and Academic Achievement in a Semi-rural Setting. Psychological Studies, 37, 2, 126-129.

[4] Chakrabarti, S., (1986) Academic Achievement of Primary School Children. The Progress of Education, 60, 9, $209-215$.

[5] Kazmi, S. Farhana, Muhammad Sajjid, Tahir Pervez (2011) Parental Style and Academic Achievement among the Students. International Journal ofAcademic Research, 3, 2.

\section{Council for Innovative Research}

Peer Review Research Publishing System

Journal of Social Science Research

\author{
Vol.1, No.1 \\ editor@ijssronline.com \\ www.cirworld.com, www.ijssronline.com
}


[6] Krishnan, A.P. (1977) Non-intellectual Factors and Their Influence on Academic Achievement.Psychological Studies, 22, 1-7.

[7] Saini, B.K. (1977) Academic Achievement As a Function of Economic Status and Educational Standard of Parents. Psychological Studies, 22, 23-28.

[8] Salami, Samuel O. (2010) Emotional Intelligence, Psychological Well- Being and Students' Attitudes: Implications for Quality Education.European Journal of Educational Studies, 2, 3, 1946- 6331.

\section{Council for Innovative Research}

Peer Review Research Publishing System

Journal of Social Science Research

Vol.1, No.1

editor@ijssronline.com

www.cirworld.com, www.ijssronline.com 